\title{
miR-329-CONTAINING EXOSOMES DERIVED FROM BREAST TUMOR CELLS SUPPRESS VEGF AND KDM1A EXPRESSION IN ENDOTHELIAL CELLS
}

\author{
N. MALEKI $I^{1,2,3 凶}$, F. KARAMI', S. HEYATI ${ }^{2}$, \\ M. HADIZADEH ${ }^{3}$, Gh. PARNIAN"凶 \\ ${ }^{1}$ Department of Cellular and Molecular Biology, Faculty of Biological Sciences, \\ Islamic Azad University-Tehran North Branch, Tehran, Iran; \\ 凶e-mail: dr.nargesmaleki@yahoo.com; \\ ${ }^{2}$ Gynecology and reproductive biology Department, Kowsar poly-clinic, Tehran, Iran; \\ ${ }^{3}$ Cancer Research Center, Shahid Beheshti University of Medical Sciences, Tehran, Iran; \\ ${ }^{4}$ Appletree Medical group, 275 Dundad W (Grange), Toronto, Ontario, Canada; \\ e-mail: ghazalehparnian1@gmail.com
}

Received: 03 February 2021; Accepted: 07 July 2021

The exosomal transfer of miRNAs from tumor cells is considered to modulate VEGF expression and angiogenesis in endothelial cells. The aim of our investigation was to focus exclusively on the ability of specific exosomal miR329 to regulate angiogenesis within breast tumor. All experiments were done on MCF-7 and HUVEC cell lines. Exosomes were derived from MCF-7 cells both untreated and treated with tamoxifen that is an effecrive suppressor of hormone receptor-positive breast cancer. The level of miR32 and its targeted genes VEGF and lysine (K)-specific demethylase $1 A$ (KDMIA) expression was estimated with q-RT-PCR. The PKH26 red fluorescent labeling kit was used to label the isolated exosomes and monitor their uptake. It was shown that the relative amount of miR-329 in exosomes was twice as large as in breast cancer cells. Fluorescence microscopy imaging presented that exosomes from MCF-7 cells were able to penetrate into endothelial cells and concentrate in the cytoplasm. It was observed that exosomes derived from untreated breast cancer cells induced KDM1A and VEGF gene expressions whereas exosomes from tamoxifen-treated cancer cells induced time-dependent decrease of KDM1A and VEGF expression in endothelial cells. It is assumed that the transfer of miR-329 containing exosomes from tamoxifen treated breast cancer cells to the endothelial cells could repress angiogenic molecular signaling pathway and be used as a supplementary strategy in breast cancer treatment.

Ke y w or d s: breast cancer, angiogenesis, exosome, miR-329, tamoxifen, VEGF, KDM1A.

$\mathrm{B}$ reast cancer $(\mathrm{BC})$ has the highest mortality prevalence in females [1]. BC tumor is surrounded by a micro-environment of various stromal cell types, which have a role in tumor progression [2], the onset of which is via angiogenesis; the new blood vessel formation process facilitating metastasizing [3].

One of the mechanisms tamoxifen takes advantage of in suppressing breast tumors is its antiangiogenic feature. ERR $\alpha$-dependent induction of VEGF [4] in the tumor microenvironment by stimulating endothelial cell proliferation and angiogenesis would lead finally to tumor progression, metastasis, and drug resistance [5-7]. Tumor neovascularization is originated and developed by the key stimulating factors of endothelial cells, VEGF and its receptors, VEGFR-1 and VEGFR-2 [8]. Although the presence of estrogen receptors on the endothelial cells can assume as the antiangiogenic function of tamoxifen, it may directly inhibit the proliferation of VEGFdependent angiogenesis surrounding the tumor environment [9].

The micro-environment and tumorigenesis of breast cancer tissue is regulated through microRNAs 
and diffusion of exosomes containing microRNAs [10]. Some microRNAs found in exosomes are thought to be specifically involved in breast tumor progression; for instance, TRPC5, miR-1246, miR21, miR-34a, Let-7 family, miR-494, miR-210, miR200 family, miR-221, miR-222, miR-23b, miR-125b, miR-105, miR-29, to name but a few. Since exosomes are a rich and protected source of microRNAs, it is presumed that the exosomal transfer of miRNAs from tumor cells to endothelial cells may be a factor in modulating VEGF expression and regulating angiogenesis. This provides the feasibility of using these regulatory non-coding, endogenous, evolutionarily-conserved RNAs as adjuvant therapy with anti-cancer treatments to enhance therapeutic efficacy [11]. Estrogens regulate miRNAs transcription through estrogen receptors $\alpha$ and $\beta$ in a tissuespecific and cell-dependent manner. It has been shown that tamoxifen alters the pattern of miRNAs by either downregulating or upregulating them [12]. Hence, the question arises whether the antiangiogenic function of tamoxifen was mediated by altered miRNA expression. MiR-329, as a deterrent factor for angiogenesis, is an "anti-angiomir", which has a negative regulatory effect on endothelial cells functions. The direct target gene of miR-329 as named KDM1A has been shown to have a direct role in the neoangiogenesis in tumor growth [13].

Considering the biological functions of exosomes, we initially evaluated whether tumor exosomes carrying microRNAs can per se regulate VEGF-related angiogenesis in vascular endothelial cells, and subsequently, we sought to determine whether tamoxifen could change the breast cancer angio-miR-329 level in breast cancer cell line MCF-7 to represent potential use of tamoxifen for developing new therapeutic strategies in breast cancer patients.

\section{Materials and Methods}

Ethics approval and consent to participate. This work has been carried out in accordance with European Convention for the protection of vertebrate animals used for experimental and other scientific purposes (Strasbourg, 1986).

Cell culture. Human breast carcinoma-derived cell line (MCF-7) and human umbilical vein endothelial cells (HUVECs) were cultured in Dulbecco's modified Eagle's medium (DMEM) supplemented with $10 \%$ heat-inactivated fetal bovine serum (FBS), 2 mM L-glutamine and 1\% antibiotics
(100 U/ml penicillin and $100 \mu \mathrm{g} / \mathrm{ml}$ streptomycin) (all from Gibco BRL, Rockville, MD, USA) at $37^{\circ} \mathrm{C}$ in a humidified atmosphere with $5 \% \mathrm{CO}_{2}$.

Tamoxifen treatment and cell viability assay (MTT). In order to reach the appropriate dosage of tamoxifen, cell viability was evaluated by the halfmaximal inhibitory concentration $\left(\mathrm{IC}_{50}\right)$ through applying 3-(4,5dimethylthiazole-2-yl)-2,5-diphenyltetrazolium bromide (MTT) to breast cells. In brief, almost 10,000 cells/well were seeded into a 96well plate in RPMI-1640 medium and were allowed to attach overnight. Subsequently, cells were treated with different ascending doses of tamoxifen and incubated for 48 hours $\left(37^{\circ} \mathrm{C}, 5 \%\right.$ carbon dioxide in the air). The effects of all doses were assessed in triplicate. Cell growth inhibition was determined using the MTT assay. The medium was removed and $20 \mu \mathrm{l}$ of the MTT ( $5 \mathrm{mg} / \mathrm{ml}$ ) (Sigma, St. Louis, MO, USA) was added to each well of the 96 -well plate and were incubated for $4 \mathrm{~h}$ at $37^{\circ} \mathrm{C}$. Composed crystals dissolved by adding $200 \mu \mathrm{l}$ of DMSO to each well. Finally, the optimal absorbance level was measured by the ELISA-Reader machine at $570 \mathrm{~nm}$.

Exosome isolation and purification. The cells were cultured in T75 flasks with $5 \times 10^{4}$ cells $/ \mathrm{cm}^{2}$, complemented with 10\% exosome-depleted serum (EXO-FBS; System Biosciences) for $48 \mathrm{~h}$. When the cells reached $80-90 \%$ confluency, at passage 3, differential centrifugation was performed. In short, around $700 \mathrm{ml}$ of the media was centrifuged at $3000 \times \mathrm{g}$ for $10 \mathrm{~min}$ at $4^{\circ} \mathrm{C}$ and then at $10,000 \times \mathrm{g}$ for $30 \mathrm{~min}$ at $4^{\circ} \mathrm{C}$ to eliminate residual cells and cellular debris, respectively. Extracellular vesicles were pelleted by ExoQuick ${ }^{\mathrm{TM}}$ Exosome Precipitation Solution kit (System Biosciences) with a ratio of 5 to 1. Exoquick (system biosciences) solution was added to the supernatant with a ratio of 5 to 1 . Isolation steps were followed per the manufacturer's instruction. Finally, exosome pellets were suspended in $50 \mu$ l PBS and stored at $-20^{\circ} \mathrm{C}$ until use.

Dynamic light scattering analysis. The dynamic light scattering (DLS) was utilized for the determination of exosomes' size, for which Zetasizer Nano ZS (Malvern Instruments, Worcestershire, $\mathrm{UK}$ ) was used based on the given protocol.

Scanning electron microscopy. The morphology and size of the purified exosomes were measured by scanning electron microscopy (Digital FESEM, KYKY-EM3200, China). For this purpose, an aliquot of the above-mentioned exosomes was fixed in $2.5 \%$ glutaraldehyde on a microscope slide, washed by PBS, and an ascending amount of ethanol was 
utilized for critical point dehydration. The slide was then dried on a glass substrate and coated with a thin layer of gold.

Exosome labeling assay. The PKH26 red fluorescent labeling kit (Sigma-Aldrich, USA) was utilized to label the isolated exosomes. The labeled exosomes were incubated with endothelial cells for $12 \mathrm{~h}$. An inverted fluorescence microscope (Olympus CKX41) was finally utilized for monitoring the fluorescence uptake.

Reverse transcription-quantitative polymerase chain reaction (RT-qPCR) analysis. Total RNA was extracted from both the cells and exosomes with TRIzol ${ }^{\circledR}$ (Invitrogen, USA). Subsequently, $1 \mu \mathrm{g}$ of RNA was reverse-transcribed into complementary DNA (cDNA), for which PrimeScript 1st Strand cDNA Synthesis kit (TAKARA Bio Inc., Otsu, Japan) was utilized. The expression levels of target genes and miR-329 were all determined by RT-qPCR using SYBR ${ }^{\circledR}$ Premix TaqT ${ }^{\mathrm{TM}}$ II (TAKARA, Japan). In this regard, the GAPDH gene was exploited as a reference gene to normalize the number of transcripts in samples. Their relative expression was indicated with mean Ct values using the method [14]. Poly-(A)-tailing and cDNA synthesis were applied by reverse transcription of $1 \mu \mathrm{g}$ total RNA, exploiting miR-Amp Kit (ParsGenome, Iran) for quantifying miR-329, and the expression levels of mature miRNA were determined using miR-329 specific primers. The expression was normalized with U6 small nuclear RNA (snRNA). The Specific Reverse and Forward primers for microRNA and target genes were obtained from Parsgenome, and their sequences were as follows: VEGF Forward primer: 5-TGCAGATTATGCGGATCAAACC-3, VEGF Reverse primer: 5-TGCATTCACATTTGTTGTGCTGTAG-3, GAPDH Forward primer: 5-ACCCACTCCTCCACCTTTGA-3, GAPDH Reverse primer: 5-CTGTTGCTGTAGCCAAATTCGT-3, U6snRNA Forward primer: 5-CTCGCTTCGGCAGCACATATACT-3, U6snRNA Reverse primer: 5-ACGCTTCACGAATTTGCGTGTC-3, KDM1A Forward primer: 5-GGGGCTCTTATTCCTATGTT-3, KDM1A Reverse primer: 5-CAAAGAAGAGTCGTGGAATC-3.

Transfer of miRNA. In order to assess the exosome transfer of miR-329 into endothelial cells, almost $3 \times 10^{4}$ cells/well were co-incubated at different times with either $100 \mu \mathrm{g} / \mathrm{ml}$ exosomes and transcription inhibitor $\alpha$-amanitin (Sigma, $50 \mu \mathrm{g} / \mathrm{ml}$ ) or just with $\alpha$-amanitin. Subsequently, endothelial cells' total RNA was isolated at time 0,12 , and 48 h post- stimulation. The difference in $\mathrm{Ct}$ values between $\alpha$-amanitin stimulated cells in the presence and absence of exosomes at each intervention time was evaluated in order to measure the exosome transfer of miRNA [15].

Statistical analysis. Data were assessed by oneway ANOVA with Graph-Pad Prism software v.5.0. All data are expressed as mean \pm SD for three experiments. $P$-value $<0.05$ was considered statistically significant for all statistical assessments.

\section{Results}

Initially, breast cancer cells were treated with various ascending dosages of tamoxifen over $48 \mathrm{~h}$ to obtain $\mathrm{IC}_{50}$. The sensitivity and tolerable dosage of tamoxifen were determined using the MTT assay. Finally, the concentration of $60 \mu \mathrm{m}$ was considered as $\mathrm{IC}_{50}$ of tamoxifen for subsequent experiments.

Isolation, characterization and cellular uptake of purified exosomes. Exosome isolation was performed to discover the paracrine effects of breast cancer exosomes on endothelial cell angiogenesis. FESEM analysis indicated that the purified exosomes had a spherical shape with an approximate diameter of $\sim 50-150 \mathrm{~nm}$ (Fig. 1, A). To examine whether exosomes could be taken up by endothelial cells, PKH26-labeled exosomes were incubated with endothelial cells for $12 \mathrm{~h}$. The results of fluorescence microscopy imaging presents that exosomes can be concentrated in the endothelial cells' cytoplasm (Fig. 1, B, C). In addition, the particle size distribution of exosomes by dynamic light scattering revealed a peak of almost $90 \mathrm{~nm}$ (Fig. 1, D).

Breast cancer cell-derived miR-329 promote in vitro angiogenesis in endothelial cells through modulating KDM1A and VEGF expression. In order to have a clear description of the molecular mechanisms by which tumor-derived exosomes promote endothelial cell angiogenesis, this paper initially hypothesized that miRNAs shuttled by breast cancer cell-derived exosomes might have a role in the pro-angiogenic effects of tumor-derived exosomes on endothelial cells. Therefore, since miR-329 is considered as a critical miRNA involved in cancer pathogenesis, as well as being enriched in breast cancer cell-derived exosomes [17], this miR has been evaluated in both the donor and the recipient cells. As shown in Fig. 2, it is highlighted that miR329 was detectable in both breast cancer cell-derived exosomes and the endothelial cells. Noticeably, no considerable amount of miR-329 was detected in 
A

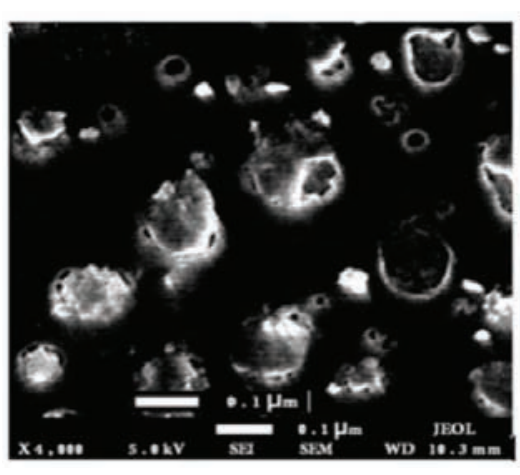

B

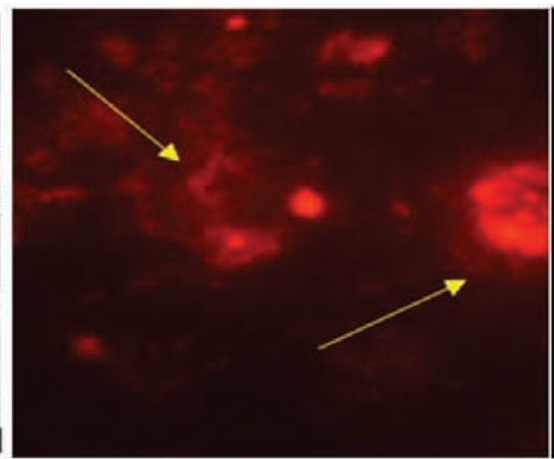

C

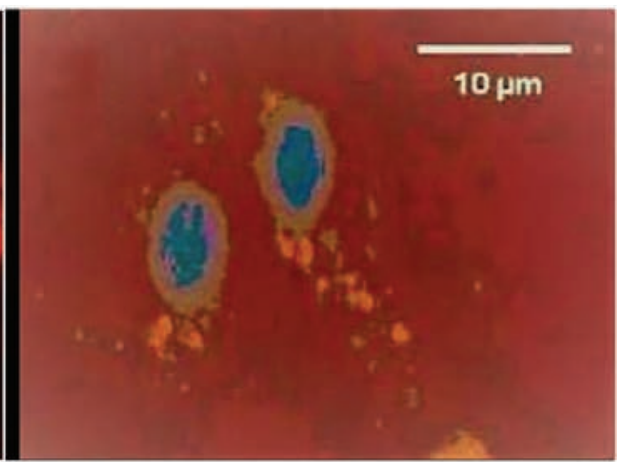

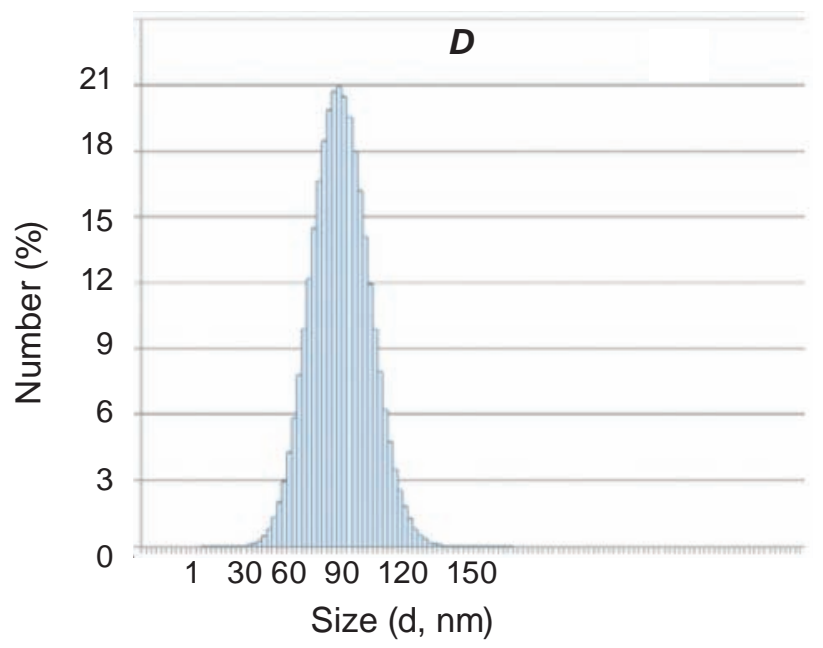

Fig. 1. Isolation, characterization and cellular uptake of purified exosomes. A: field emission scanning electron microscopy graph of purified exosomes depicting spherical and membrane-encapsulated particles with diameters ranging from 30 to $150 \mathrm{~nm}$. B: internalization of breast cancer cells' exosomes into endothelial cells. A red fluorescence in the cytoplasm of the endothelial cells indicates that significant amounts of breast cancer cells' exosomes are taken up by the cells. $C$ : the merged photo, which determined the capability of breast cancer exosomes to penetrate into the recipient cells. $\boldsymbol{D}$ : distribution measurement of isolated exosomes proved a peak of approximately $90 \mathrm{~nm}$ diameter through dynamic light scattering (DLS)

normal epithelial cells' exosomes. All experiments were done on MCF-7 and HUVECs cell lines.

Tamoxifen-treated breast cancer cell-derived exosomes down-regulated the gene expression of angiogenesis. After tamoxifen-treated/untreated exosomes being encountered with breast cancer cell-derived endothelial cells, the expression level of two angiogenic factors, VEGF and KDM1A, were quantified. It was observed that tumor cell-derived exosomes, which are tamoxifen-untreated, induced more KDM1A and VEGF gene expressions in a time-dependent manner. However, endothelial cells confrontation with tamoxifen-treated exosomes had a time-dependent downward KDM1A and VEGF expression. It can be concluded that the high amount of miR-329 in the exosomes from tamoxifen-treated breast cancer cells, could significantly reduce $K D M 1 A$ and $V E G F$ expression in the endothelial cells after 24 and $48 \mathrm{~h}$. As are shown in Fig. 3 (A and $B$ ), both $K D M 1 A$ and $V E G F$ genes were downregulated time-dependently.

\section{Discussion}

Intercellular interaction plays a vital role in microenvironment equilibrium. Numerous studies support the participation of exosomes in this bioactivity, and since they are filled up with various miRs, there is an ongoing notion that miRs partake in tissue hemostasis and reciprocation [17]. Tumor cells are not excluded from this creed. In other words, in a carcinogenic microenvironment, normal unaffected cells are surrounded by tumor-associated fibroblasts, vas- 


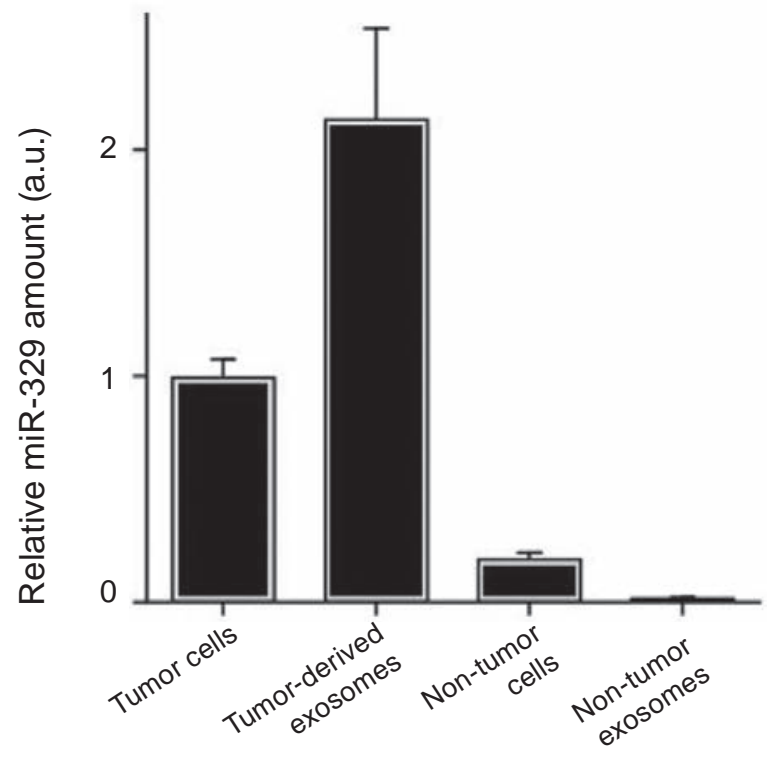

Fig. 2. Exosome transfer of miR-329 up-regulates the in vitro angiogenesis in endothelial cells through modulating KDM1A and VEGF expression. The relative amount of miR-329 in tumor cells is considered as the base, and then the relative amount of miR-329 in tumor-derived exosomes has been detected as two times more than the tumor cell-line. In contrast, the relative amount of miR-329 in normal non-cancerous breast cell line and non-tumor exosomes were greatly lower than the base line. All results have been produced with RT-qPCR

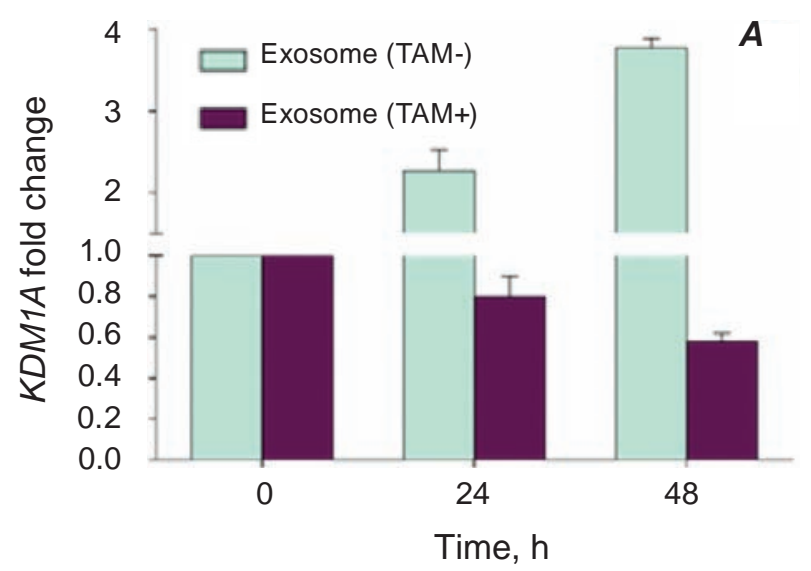

cular endothelial cells, inflammatory agents, to name but a few, which have proved negative consequences on their normal adjacent cells [18].

Neovascularization is an essential part of tumor development since newly invaded parts are in need of blood for maintenance and metastasis, which is modulated fundamentally by the tumor microenvironment. Consequently, the alteration of normal cells to cancerous cells occurs [19]. Regulation of vascular endothelial cells' roles is performed by the extracellular matrix (ECM). Vascular Endothelial Growth Factor (VEGF) acts as a mitogen for vascular endothelial cells derived from arteries, veins, and lymph vessels, increases angiogenesis and metastasis, increases vascular permeability, leads to the development of extracellular membrane, and therefore, it helps tumor growth [20].

Lately, the positive impact of tumor-derived exosomes on VEGF expression and consequently vascular endothelial cells' development has been identified [16] and some papers have suggested the modulating role of microRNAs, one of the exosomes' secretions in this pathway, through the discharge of which messages are transferred from tumorigenic cells to their neighbor's cells [21]. KDM1A is involved in carcinogenesis as one of the important epigenetic regulators. Moreover, it is a direct target gene for miR-329. KDM1A is used as

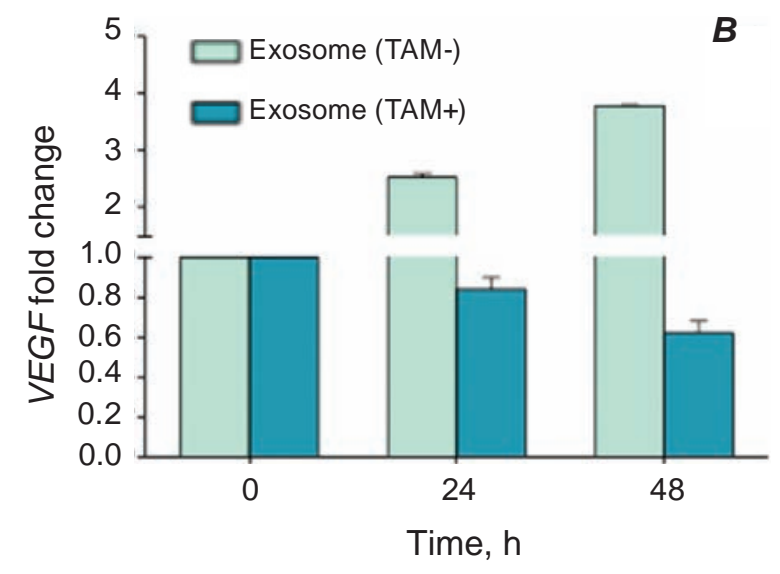

Fig. 3. Inhibitory effect of tamoxifen-treated exosomes on regulating the angiogenesis of endothelial cell. Angiogenesis measured by quantifying the level of VEGF and KDMIA expression over time by q-RT-PCR. To evaluate whether the tamoxifen-treated exosomal miR-329 has the estimated function or not, VEGF and KDM1A expression levels were analyzed in endothelial cells treated with $100 \mu \mathrm{g} / \mathrm{ml}$ breast cancer cell-derived exosomes. A: evaluation of KDMIA expression is shown in two different-colored bars indicating two subgroups of tamoxifen-treated exosomes and untreated subgroup (control group). B: evaluation of VEGF expression is shown in two different-colored bars indicating two subgroups of exosomes derived from tamoxifen-treated or untreated cells (control group) 
a cancer diagnostic biomarker and if it has a positive expression algorithm, the condition would result in a poor prognosis of cancer. There is a positive and direct relationship between the expression levels of KDM1A and VEGF-A in angiogenesis [22]. Among the predicted targets of miR-329, KDM1A and VEGF are the genes that have been found to be down-regulated in human breast cancer post-tamoxifen-treatment while being up-regulated if being left untreated [23]. In this regard, we initially evaluated the impact of exosomal miR-329 on VEGF and KDM1A signaling in endothelial cells and deduced that tamoxifen-treated, transferred breast cancer exosomes significantly decline the tumor proliferation level in angiogenesis via down-regulation of VEGF and KDM1A in endothelial cells in a time-dependent manner (Fig. 3). To the best of our knowledge, our research was the first to demonstrate the exosomal miRNA-329 from human breast cancer cells may suppress in vitro angiogenesis through modulating angiogenic factors and receptors. In this relation, it was seen that the control subgroup upregulated target gene expression, KDM1A and VEGF, in the endothelial microenvironment while in the intervention group the target genes' expression were downregulated (Fig. 3). The results of our study lend support to the notions of other previous researchers' works, which declare that tamoxifen-treated breast cancer cellular exosomes may suppress in vitro angiogenesis through downward adjusting of VEGF gene via an angiogenic molecular signaling pathway in breast cancer [24, 25].

Conclusion. In conclusion, we deduced that exosomes derived from breast cancer cells have the capability to up-regulate VEGF and KDM1A expression and signaling in endothelial cells. Novelty of this project was assessing the impacts of breast cancer cell-derived exosomal miR-329 on behavior of endothelial cells, specifically angiogenesis progression. Finally, by further research on the functions of cancer-derived exosomes and broaden the horizons of tumor microenvironment, evaluation of different new drugs with better tolerance and the least resistance could be sought.

Conflict of interest. Authors have completed the Unified Conflicts of Interest form at http://ukrbiochemjournal.org/wp-content/uploads/2018/12/ coi_disclosure.pdf and declare no conflict of interest.
Acknowledgements. The practical stage of this research was done at the Genetic Laboratory, Gynecology and reproductive biology Department, Kowsar poly-clinic, Tehran, Iran. Thus, their spirtual support is highly appreciated.

ЕКЗОСОМИ 3 miR-329, ОДЕРЖАНІ
3 КЛІТИН ПУХЛИНИ ГРУДНӦ̈
ЗАЛОЗИ ПРИГНІЧУЮТЬ
ЕКСПРЕСІЮ VЕGF ТА КDM1А В
ЕНДОТЕЛІАЛЬНИХ КЛІТИНАХ

$$
\begin{aligned}
& \text { N. Maleki }{ }^{1,2,3 凶}, \text { F. Karami }{ }^{1} \text {, S. Heyati }{ }^{2} \text {, } \\
& \text { M. Hadizadeh }{ }^{3} \text {, Gh. Parnian }{ }^{4 \bowtie}
\end{aligned}
$$

Вважається, що перенесення miRNA з екзосом пухлинних клітин модулює експресію генів VEGF та ангіогенез в ендотеліальних клітинах. Метою нашого дослідження було з'ясувати здатність екзосомної miR329 регулювати ангіогенез у пухлині грудної залози. Експерименти проводили на клітинних лініях MCF-7 та HUVEC. Екзосоми одержували 3 клітин MCF-7, необроблених і оброблених тамоксифеном - ефективним супресором гормонзалежного раку грудної залози. За допомогою q-RT-PCR кількісно визначали рівні експресії miR329, ïi таргетних генів VEGF і лізин- (K)-специфічної деметилази $1 \mathrm{~A}$ $(K D M 1 A)$. Для флуоресцентного маркування ізольованих екзосом та моніторингу їх поглинання використовували барвник РКН26. Згідно з даними флуоресцентної мікроскопії, одержані $з$ клітин MCF-7 екзосоми проникали в ендотеліальні клітини та накопичувалися в цитоплазмі. Показано, що екзосоми, одержані 3 необроблених пухлинних клітин, посилювали експресію генів $V E G F$ та KDM1A залежно від часу інкубації, тоді як екзосоми з оброблених тамоксифеном клітин 
спричиняли залежне від часу пригнічення експресії VEGF та KDM1A в ендотеліальних клітинах. Припускається, що перенесення екзосомної miR-329 від оброблених тамоксифеном пухлинних клітин грудної залози до ендотеліальних клітин пригнічує молекулярний ангіогенний сигнальний шлях і може використовуватись як додаткова стратегія лікування раку грудної залози.

К л ю ч о в і с л о в а: рак грудної залози, ангіогенез, екзосома, miR-329, тамоксифен, VEGF, KDM1A.

\section{References}

1. Takahashi RU, Miyazaki H, Ochiya T. The roles of microRNAs in breast cancer. Cancers (Basel). 2015; 7(2): 598-616.

2. Penfornis P, Vallabhaneni KC, Whitt J, Pochampally R. Extracellular vesicles as carriers of microRNA, proteins and lipids in tumor microenvironment. Int $J$ Cancer. 2016; 138(1): 14-21.

3. Bachawal S, Bean GR, Krings G, Wilson KE. Evaluation of ductal carcinoma in situ grade via triple-modal molecular imaging of $\mathrm{B} 7-\mathrm{H} 3$ expression. NPJ Breast Cancer. 2020; 6: 14.

4. Stein RA, Gaillard S, McDonnell DP. Estrogenrelated receptor alpha induces the expression of vascular endothelial growth factor in breast cancer cells. J Steroid Biochem Mol Biol. 2009; 114(1-2): 106-112.

5. Hida K, Maishi N, Sakurai Y, Hida Y, Harashima H. Heterogeneity of tumor endothelial cells and drug delivery. Adv Drug Deliv Rev. 2016; 99(Pt B): 140-147.

6. Hida K, Hida Y, Shindoh M. Understanding tumor endothelial cell abnormalities to develop ideal anti-angiogenic therapies. Cancer Sci. 2008; 99(3): 459-466.

7. Goel S, Duda DG, Xu L, Munn LL, Boucher Y, Fukumura D, Jain RK. Normalization of the vasculature for treatment of cancer and other diseases. Physiol Rev. 2011; 91(3): 1071-1121.

8. Hicklin DJ, Ellis LM. Role of the vascular endothelial growth factor pathway in tumor growth and angiogenesis. J Clin Oncol. 2005; 23(5): 1011-1027.

9. McNamara DA, Harmey J, Wang JH, Kay E, Walsh TN, Bouchier-Hayes DJ. Tamoxifen inhibits endothelial cell proliferation and attenuates VEGF-mediated angiogenesis and migration in vivo. Eur J Surg Oncol. 2001; 27(8): 714-718.

10. Abounit S, Zurzolo C. Wiring through tunneling nanotubes - from electrical signals to organelle transfer. J Cell Sci. 2012; 125(Pt 5): 1089-1098.

11. Lowery AJ, Miller N, McNeill RE, Kerin MJ. MicroRNAs as prognostic indicators and therapeutic targets: potential effect on breast cancer management. Clin Cancer Res. 2008; 14(2): 360-365.

12. Klinge CM. miRNAs regulated by estrogens, tamoxifen, and endocrine disruptors and their downstream gene targets. Mol Cell Endocrinol. 2015; 418(Pt 3): 273-297.

13. Yang H, Li Q, Zhao W, Yuan D, Zhao H, Zhou Y. miR-329 suppresses the growth and motility of neuroblastoma by targeting KDM1A. FEBS Lett. 2014; 588(1): 192-197.

14. Nosaeid MH, Mahdian R, Jamali S, Maryami F, Babashah S, Maryami F, Karimipoor M, Zeinali S. Validation and comparison of two quantitative real-time PCR assays for direct detection of DMD/BMD carriers. Clin Biochem. 2009; 42(12): 1291-1299.

15. Collino F, Deregibus MC, Bruno S, Sterpone L, Aghemo G, Viltono L, Tetta C, Camussi G. Microvesicles derived from adult human bone marrow and tissue specific mesenchymal stem cells shuttle selected pattern of miRNAs. PLoS One. 2010; 5(7): e11803.

16. Weis SM, Cheresh DA. Tumor angiogenesis: molecular pathways and therapeutic targets. Nat Med. 2011; 17(11): 1359-1370.

17. Babashah S. MicroRNAs: Key Regulators of Oncogenesis. Springer, 2014. 433 p.

18. Babashah S, Soleimani M. The oncogenic and tumour suppressive roles of microRNAs in cancer and apoptosis. Eur J Cancer. 2011; 47(8): 1127-1137.

19. Folkman J. Angiogenesis. Annu Rev Med. 2006; 57: 1-18.

20. Makrilia N, Lappa T, Xyla V, Nikolaidis I, Syrigos $\mathrm{K}$. The role of angiogenesis in solid tumours: an overview. Eur J Intern Med. 2009; 20(7): 663-671.

21. Lee Y, El Andaloussi S, Wood MJ. Exosomes and microvesicles: extracellular vesicles for genetic information transfer and gene therapy. Hum $\mathrm{Mol}$ Genet. 2012; 21(R1): R125-R134. 
22. Kashyap V, Ahmad S, Nilsson EM, Helczynski L, Kenna S, Persson JL, Gudas LJ, Mongan NP. The lysine specific demethylase-1 (LSD1/KDM1A) regulates VEGF-A expression in prostate cancer. Mol Oncol. 2013; 7(3): 555-566.

23. Rotundo MS, Galeano T, Tassone P, Tagliaferri P. mTOR inhibitors, a new era for metastatic luminal HER2-negative breast cancer? A systematic review and a meta-analysis of randomized trials. Oncotarget. 2016; 7(19): 27055-27066.

24. Lee TH, Seng S, Sekine M, Hinton C, Fu Y, Avraham HK, Avraham S. Vascular endothelial growth factor mediates intracrine survival in human breast carcinoma cells through internally expressed VEGFR1/FLT1. PLoS Med. 2007; 4(6): e186.

25. Lee JK, Park SR, Jung BK, Jeon YK, Lee YS, Kim MK, Kim YG, Jang JY, Kim CW. Exosomes derived from mesenchymal stem cells suppress angiogenesis by down-regulating VEGF expression in breast cancer cells. PLoS One. 2013; 8(12): e84256. 